\title{
Response Surface Methodology to Evaluation the Recovery of Amylases by Hollow Fiber Membrane
}

\author{
João Baptista Severo Júnior ${ }^{1}$, Laura Sampaio de Sá Oliveira ${ }^{1}$, Fernanda Silva Sardeiro ${ }^{1}$, \\ Roberto Rodrigues de Souza ${ }^{1}$, Francisco Luiz Gumes Lopes ${ }^{2}$, José Carlos Curvelo Santana ${ }^{2}$ \\ and Elias Basile Tambourgi ${ }^{2} *$ \\ ${ }^{I}$ Departamento de Engenharia Química; Universidade Federal de Sergipe; Cidade Universitária "Prof. José Aloísio de \\ Campos"; Av. Marechal Rondon, s/n; Rosa Elze; 49100-000; São Cristóvão - SE - Brasil. ${ }^{2}$ Departamento de \\ Engenharia de Sistemas Químicos; Faculdade de Engenharia Química; Universidade Estadual de Campinas; Cidade \\ Universitária "Zeferino Vaz"; Av. Albert Einstein, 500; C.P. 6066; Barão Geraldo; eliast@feq.unicamp.br; 13083- \\ 970; Campinas - SP - Brasil
}

\begin{abstract}
This work aimed to study the $\mathrm{pH}$ and the transmembrane pressure effects during the recovery of $\alpha$ and $\beta$ amylases enzymes from corn malt (Zea mays) by hollow fiber membrane. The optimal condition was obtained for a statistical model, established by response surface methodology (RSM). The response surface analysis showed that the best operation condition for amylolitics enzymes recovery by hollow fiber membrane was 0.05 bar and pH 5.00, while the enzymes were purified about of 26 times.
\end{abstract}

Key words: Hollow fiber membrane, corn malt, $\alpha$ and $\beta$ amylase, RSM

\section{INTRODUCTION}

Of late, the use of enzymes in feeding, pharmaceutics, textile and others industries is increased for being economically viable. They are also used in the manufacture of alcoholic drinks, detergent, biosensors, and diagnostic kits and in the management of environment polluents (Jesus, 2002). $\alpha$ and $\beta$ - amylases are commercial enzymes used its many applications, mainly in the starch hydrolyses (Fogarty and Kelly, 1979; Wiseman, 1987). They are obtained commonly from barley malt or microorganisms.

$\alpha$-amylase (EC 3.3.1.1; $\alpha$ - 1,4 glucan, 4 glucanhydroxilase) is extracellulas enzyme that hydrolyses of the $\alpha-1,4$ bonds, of the amylose, amylopectin, glycogen and dextrin molecules, but can not hydrolyses a-1,6 bonds. It has molecular weight about $50 \mathrm{kDa}$, with isoelectric point 5.4 , very good enzymatic activity about $\mathrm{pH} 4.7$ and 75 ${ }^{\circ} \mathrm{C}$ (properties enzymes depends from source) (Reguly, 1996; Wiseman, 1987).

$\beta$-amylase $\quad($ EC $\quad 3.2 .1 .1, \quad \alpha-1,4$, glucanmalthydrolase) is a extracellular enzyme that hydrolyses of amylopectin and glycogen, breaking each second $\alpha-1,4$ bond. It has molecular weight about $50 \mathrm{kDa}$, with isoelectric point 5.4 , very good enzymatic activity about $\mathrm{pH}$ 4.5-6.5 and 55-57 ${ }^{\circ} \mathrm{C}$, it is inactive after temperatures above of $60{ }^{\circ} \mathrm{C}$ (Reguly, 1996; Wiseman, 1987).

In biotechnology, separation and purification of biomolecules from large-scale fermentation represents the major manufacturing cost, therefore

\footnotetext{
${ }^{*}$ Author for correspondence
} 
competitive advantage in commercialization will depend not only on biomolecule production, but also on innovation and optimization of downstream process. Downstream process more recent were appeared in this last time with the biotechnology advances, principally, with the several genes sequencing of divers organisms, including to the full human genome, the three principals separation process are: aqueous twophase systems extraction, membrane separation and fluidized bed sorption (Asenjo, 1990).

Membranes separation process is an existing alternative among separation processes that it has been more used in recent years. A membrane is defined as a barrier to separate two phases and total restricting or presented various chemical species partial transporting into phase. The membrane controls the species transporting relative rate and, as all separation, furnishes one exit current that is poor in certain components and another, rich in these components (Cheryan, 1986; Noble and Way, 1993).

Cross flow filtration occurs when to solution or suspension flow runs parallel to the membrane and perpendicular to the permeate flow. The processes that involve cross flow filtration are used to recovery, to concentrate or to purify solutions. One of the principal membrane modules utilized in cross flow filtration is the flat membranes of plates and blocks (Santos, 1996).

Processes with membranes become viable in an industrial scale with the adequate choice of membranes to the processing of each determined product (Basseti, 2002).

Response surface methodology (RSM) is a tool very used in process optimization, due to be easily application and fast response. The analysis of variance (ANOVA) is employed for the determination of significant variables. ANOVA consists of classifying and cross-classifying statistical results and was tested by the means of a specified classification difference, which was carried out by Fisher's statistical test ( $F$-test). The $F$-value is defined as the ratio of the mean square of regression (MRR) to the error (MRe) $(F=\mathrm{MRR} / \mathrm{MRe})$, representing the significance of each controlled variable on the tested model. The regression equations were also submitted to the $F$ - test to determine the coefficient $R^{2}$ (Barros Neto et al., 2001; Higuti et al., 2004).

This work aimed to study the effect of the $\mathrm{pH}$ and of the transmembrane pressure during the recovery of the $\alpha$ and $\beta$ amylases enzymes from corn malt (Zea mays) by hollow fiber membrane the optimal conditions obtaining it was for a statistical model, established by response surface methodology (RSM).

\section{MATERIALS AND METHODS}

\section{Maize malt obtaining}

The maize seeds were selected, their weight was measured, washed, the seeds were carried to water absorption until 40- $45 \%(\mathrm{w} / \mathrm{w})$ and germinated in laboratory. The germination time was between 4 5 days. The maize malt was dried at $55^{\circ} \mathrm{C}$ (Biazus et al., 2005; Malavasi et al., 2004; Santana, 2003).

\section{Enzyme activity}

Amylase was assayed according to Milles laboratory method Nirmala and Muralikrishna (2003), Reguly (1996). $20 \mathrm{~mL}$ of $2 \%$ soluble starch at $\mathrm{pH} 4.8(0.1 \mathrm{M}$ acetate buffer $)$ were hydrolyzed by $500 \mu \mathrm{L}$ of enzyme sample in $10 \mathrm{~min}$ at $37{ }^{\circ} \mathrm{C}$. One unit of enzyme activity was defined as $\mu$ mol of glucose released for min under the assay conditions. The specific activity was calculated as activity for $\mathrm{mg}$ protein.

\section{Total protein content}

It was determined according to the dye binding method of Bradford (1976) with bovine serum albumin as protein standard.

\section{Membrane module}

The experiments were conducted in a module of membrane of hollow fiber type (MMHF-01), that is shown in Figure 1. The polyssulfone membranes (AMICON - H1MP01-43 model) used had an area of $0.03 \mathrm{~m}^{2}$ and a pore size of $0.1 \mu \mathrm{m}$. Under the $\mathrm{pH}$ and pressure used in assay (to see Table 1), 2\% corn malt was used with feed, the flow was circulated tangentially to the membrane surface, until full-process. 


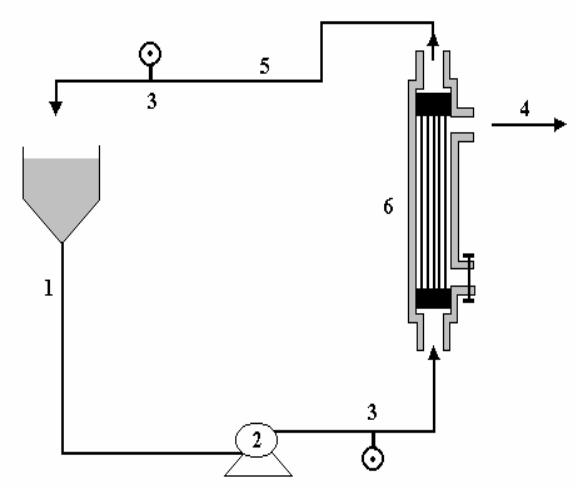

Figure 1 - Experimental MMHF-01 Microfiltration Unit.

Where: 1 - feed flow, 2 - pump, 3 - manometer, 4 - permeate, 5 - concentrate, 6 - hollow fiber membrane.

\section{Experimental design}

The influence of transmembrane pressure $(\boldsymbol{P})$ and of $\mathrm{pH}$ on purification factor $(\boldsymbol{P F})$ of $\alpha$ and $\beta$ amylases enzymes from corn malt (Zea mays) were studied by $2^{2}$ experimental planning with hexagon design (showed in Table 1), and response surface methodology (RSM) was used for optimization of recovering process. The least square method was used to estimate the model parameters, and the model fitting was made by analysis of variance methodology (ANOVA), all showed in Barros Neto et al. (1995 and 2001). The following variables codifications were used:

$$
x_{1}=p H-6
$$

$$
x_{2}=\frac{P-0.10}{0.05}
$$

\section{RESULTS AND DISCUSSION}

Experimental results obtained in this work are shown in Table 1, which describes the assays carried out to optimize the recovery of $\alpha$ and $\beta$ amylases enzymes.

Table 2 is contained the results of the statistical analysis of model validity by the analysis of variance methodology (ANOVA) to obtain the optimal empirical model for describing the system behavior studied Barros Neto et al., (1995 and 2001).

Table 1 - Planning matrix of the experiments with the optimal model data.

\begin{tabular}{ccccccc}
\hline Assays & $\boldsymbol{x}_{\boldsymbol{1}}$ & $\boldsymbol{x}_{\mathbf{2}}$ & $\boldsymbol{p H}$ & $\boldsymbol{P}(\mathbf{b a r})$ & $\boldsymbol{P F}_{\text {exp. }}$ & $\boldsymbol{P F}_{\text {pred }}$ \\
\hline 1 & -1 & -1 & 5.00 & 0.05 & 26.2488 & 25.9385 \\
2 & 1 & -1 & 7.00 & 0.05 & 4.3314 & 4.6417 \\
3 & -1 & 1 & 5.00 & 0.15 & 1.9514 & 1.6411 \\
4 & 1 & 1 & 7.00 & 0.15 & 3.7225 & 4.0327 \\
5 & 0 & 0 & 6.00 & 0.10 & 3.5204 & 4.9195 \\
6 & 0 & 0 & 6.00 & 0.10 & 5.2900 & 4.9195 \\
7 & 0 & 0 & 6.00 & 0.10 & 5.9480 & 4.9195 \\
8 & -1.41 & 0 & 4.59 & 0.10 & 13.8103 & 14.2491 \\
9 & 1.41 & 0 & 7.41 & 0.10 & 1.3200 & 0.8811 \\
\hline
\end{tabular}


Table 2 - Variance analysis (ANOVA) of the fitting model.

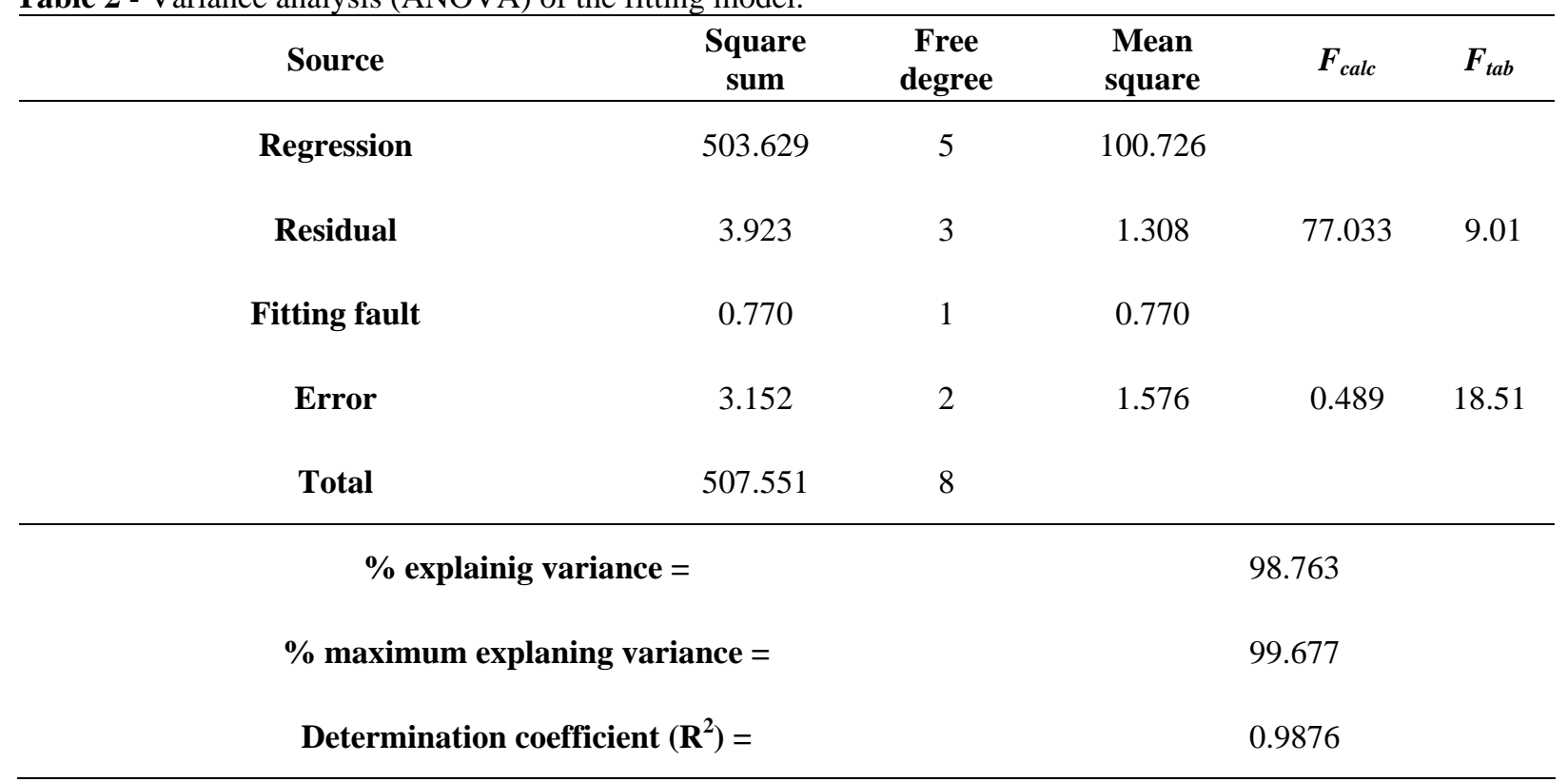

Results of the $\mathrm{F}$ test, whole the first test $\left(\boldsymbol{F}_{\text {calc }} / \boldsymbol{F}_{\text {tab }}\right)$ indicated that the model was statistical significant and the predict data were approaching the experimental data. The second test $\left(\boldsymbol{F}_{\text {tab }} / \boldsymbol{F}_{\text {calc }}\right)$ indicated that the data were fitting and they were statically representing the response surface. For the $\boldsymbol{F}$ tests are statistical considerate the rate much be equal or more that 4 (Barros Neto et al. 1995). According to Barros Neto et al. (1995) bout $\mathrm{F}$ test must be $>4$ for the model is statistical significant and predictive.

$$
\begin{aligned}
& P F=176.0011-32.5471 p H-1060.2499 P+118.4425(p H) \cdot(P)+\ldots \\
& \ldots+1.3308 p H^{2}+1125.3168 P^{2}
\end{aligned}
$$

In Figs. 2 and 3 the response surface and contour lines generated by data plotting of the optimal curve (Equation 2) for purification factor (PF) as a function of the factors are shown.

The increase of transmembrane pressure can to provoke a modification in the structure conformational of the enzymes, through of the passage by membrane pores, decreasing the specific enzymatic activity of amylolitics enzymes during the separation process, verified by the loss of activity (seen Figures 2 and 3). Behavior similar it was obtained in Lopes et al. (2004 and 2005), during the recovery of bromelain enzymes from pineapple by membranes.
Results showed that the model was statically significant and that the data get to describe well the response surface.

Equation 3 gives purification factor $(\boldsymbol{P F})$ as a function of factors $\boldsymbol{x}_{1}(\boldsymbol{p H})$ and $\boldsymbol{x}_{2} \quad(\boldsymbol{P}$, transmembrane pressure) as a square empirical model obtained by quadratic regression. This empirical model shows responses on individual and multiple effects of the factors Barros Neto et al., (1995 and 2001).
Aforesaid behavior it was observed with the increase of the $\mathrm{pH}$ modifying the structure conformational of the enzymes due the alterations in the hydrogenionic concentration, decreasing the specific activity enzymatic of the amylolitics enzymes (Borzani et al., 2001).

Through analysis of these surfaces it can be observed that purification factor increased with reduction of the transmembrane pressure and of the $\mathrm{pH}$. This shows that the best operational conditions for $\alpha$ and $\beta$ amylase enzymes recovery by the hollow fiber membrane were a transmembrane pressure of 0.05 bar and a $\mathrm{pH}$ of 5.00 . 


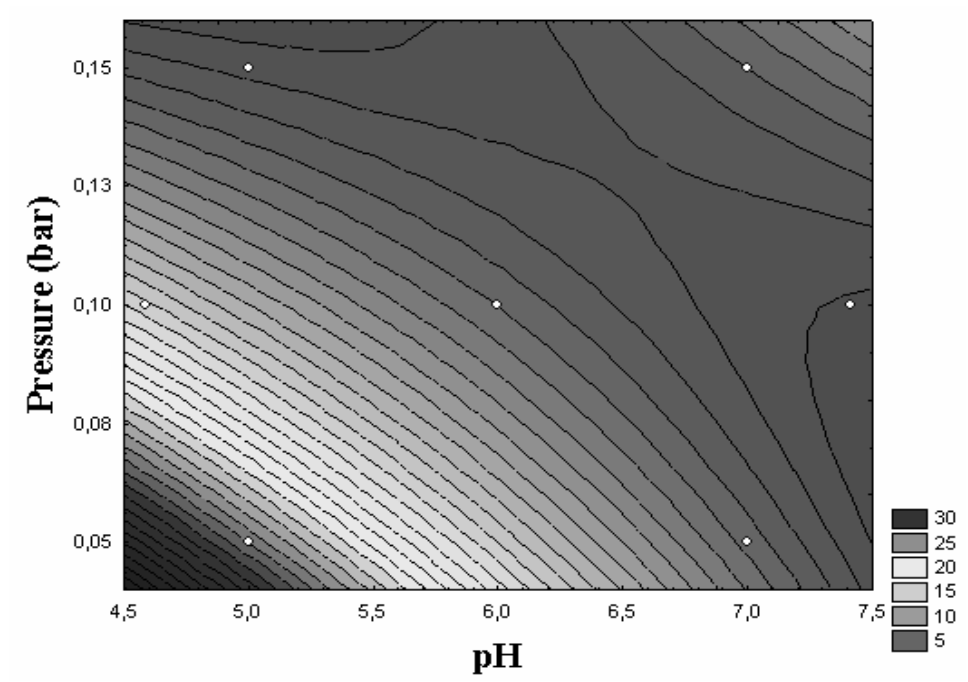

Figure 2 - 2D response surface for understanding the purification factor dependency with the $\mathrm{pH}$ and transmembrane pressure during the microfiltration of $\alpha$ e $\beta$ amylases from corn malt.

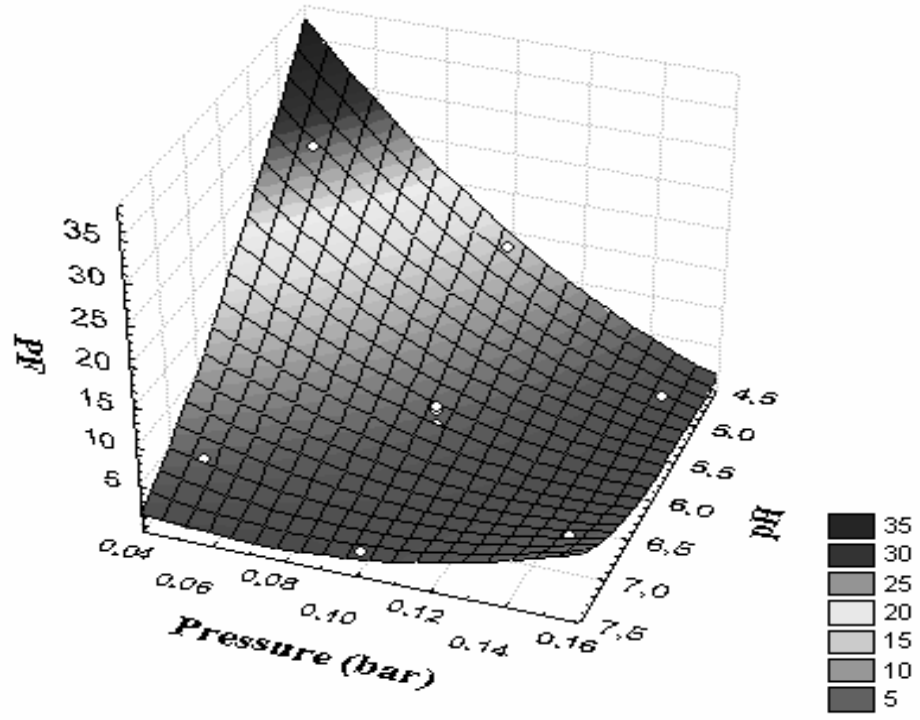

Figure 2 - 3D response surface for understanding the purification factor dependency with the $\mathrm{pH}$ and transmembrane pressure during the microfiltration of $\alpha$ e $\beta$ amylases from corn malt.

\section{CONCLUSIONS}

Under the conditions adopted for this research, and based on the results obtained, the following conclusions can be reached:

- $\quad$ The variance analysis (ANOVA) showed that the best fitting model introduced a square dependency of the purification factor, with the $\mathrm{pH}$ and the transmembrane pressure.

- $\quad$ The response surface analysis showed that the best operation condition for amylolitics enzymes recovery by hollow fiber membrane was 0.05 bar and $\mathrm{pH} 5.00$. 


\section{RESUMO}

Este trabalho objetivou estudar o efeito do $\mathrm{pH}$ e da pressão trans-membrana durante a recuperação das enzimas $\alpha$ e $\beta$ amilases do malte de milho (Zea mays) por membranas de fibras ocas, a obtenção das condições ótimas foi feita por um modelo estatístico, estabelecido pela metodologia de superfície de resposta (RSM). A análise da superfície de resposta mostrou que as melhores condições operacionais para a recuperação das enzimas amiloliticas por membranas de fibras ocas foi 0,05 bar e $\mathrm{pH} 5,00$; onde as enzimas foram purificadas cerca de 26 vezes.

\section{REFERENCES}

Asenjo, J. A. (1990) Separation process. Selection of operation process. In: Separation Process in Biotechnology; Asenjo, J. A. (ed.); Marcel Dekker: New York - EUA, 3-16.

Barros Neto, B.; Scarminio, I. S. and Bruns, R. E. (1995) Planejamento e Otimização de Experimentos. Campinas : EDUNICAMP, pp. 302.

Barros Neto, B.; Scarminio, I. S. and Bruns, R. E. (2001), Como Fazer Experimentos: Pesquisa e Desenvolvimento na Ciência e na Indústria. Campinas: EDUNICAMP, pp. 406.

Bassetti, F. J. (2002) Preparação, caracterização $e$ aplicação de membranas poliméricas microporosas assimétricas. Doctoral Thesis. Campinas, SP, Brasil, FEQ/UNICAMP.

Biazus, J. P. M.: Souza, A. G.; Santana, J. C. C. Souza, R. R.; Tambourgi, E. B. (2005), Optimization of drying process of Zea mays malt to use as alternative source of amylolytics enzymes. Brazilian Archive of Biology and Technology, v.48, Special n.6: 185-190.

Borzani,W.; Aquarone, E.; Lima, U. A.; Schmidell, W; (2001) Biotecnologia Industrial: Fundamentos, Vol. 1, $1^{\text {a }}$ Edição, Editora Edgard Blucher Ltda, São Paulo - Brasil, pp.254.

Bradford, M. M., A Rapid and Sensitive Method for the Quantitation of Microgram Quantities of Protein. Utilizing the Principle of Protein-Dye Binding. Anal. Biochem., 72, 1976, 248-254.

Cheryan, M. (1986) Ultrafiltration Handbook, Lancaster, Technomic Publishing Company, Inc.

Forgaty, W. M. and Kelly, C. T. (1979) Topics in Enzyme and Fermentation. Biotechnolog. J. Wiley and Sons. v. 3.
Higuti, I. H.; Silva, P. A.Papp, J.; Okiyama, V. M. O.; Andrade, E. A.; Marcondes. A. A. and Nascimento, A. J. (2004), Colorimetric determination of $\alpha$ and $\beta$ cyclodextrins and studies on optimization of CGTase production from $B$. firmus using factorial designs. Brazilian Archives of Biology and Technology, v.47, n. 6: 837-841.

Jesus, S. S. (2002) Desenvolvimento e Análise do Processo de Secagem de a-amilase por Microondas à Vácuo. MSc Thesis, Campinas -SP: FEQ/ UNICAMP. pp. 13-15.

Lopes, F. L. G.; Severo Júnior, J. B.; Bispo, I. M. B. D.; Santana, J. C. C.; Tambourgi, E. B.; Souza, R. R. (2004) Obtenção da condição ótima de operação para a recuperação da bromelina, do Ananas comosus, utilizando sistema de membranas planas. In: (CD) Anais do XV Congresso Brasileiro de Engenharia Química, Curitiba, EDUFPR.

Lopes, F. L. G.; Severo Júnior, J. B.; Correia E. C. O.; Santana, J. C. C.; Tambourgi, E. B.; Souza, R. R. (2005) Recuperação de enzimas bromelinas presentes no suco do Ananas comosus utilizando membranas de fibras ocas. In: $X v$ Simpósio Nacional das Fermentações, Recife, Produzido pela UFPE.

Malavasi, U. C. and Malavasi, M. M. (2004), Dormancy breaking and germination of Enterolobium contortisiliquum (Vell.) morong seed. Brazilian Archives of Biology and Technology, v.47, n.6: 851854.

Nirmala, M. and Muralikrishna, G. (2003) Three $\alpha$ amylase from malted finger millet (Ragi, Eleusine coracana, Indaf-15) - Purification and partial characterization. Phytochemistry 62, 21-23.

Noble, R. D. and Way, J. D. (1993) Description of facilitated transport and enviromental applications. Membrane processes in separation and purification. London, Kluwer Academic Publishers. 1993, (Nato ASI Series, v. 272).

Reguly, J. C., Biotecnologia dos Processos Fermentativos. EDUFPel. 1996, v. 1.

Santana, J. C. C. (2003) Recuperação das Enzimas a e (-amilases em Sistema Bifásico Aquoso PEG/ $\mathrm{CaCl}_{2}$ para Uso como Biocatalizador de Amiláceos. MSc Thesis, Campinas -SP, FEQ/ UNICAMP. pp. 232.

Santos JAL (1996) Estudo de separação de uma proteína recombinante por processos de membranas. Doctoral Thesis. Lisboa, Portugal: IST.

Wiseman, A. (1987), Handbook of Enzyme Biotechnology. 2. ed. New York, EUA: John Wiley Sons.

Received: October 06, 2005; Revised: May 26, 2006; Accepted: March 20, 2007. 